\title{
PENULTIMATE PERSPECTIVES ON THE ROOT CAUSES OF ENVIRONMENTAL DESTRUCTION IN AFRICA ${ }^{1}$
}

\author{
Ernst M Conradie \\ Department of Religion and Theology \\ University of the Western Cape
}

\begin{abstract}
In Christian ecotheology in the African context the root causes of environmental destruction in Africa are rightly associated with imperialism and colonialism. In this contribution such root causes are investigated in more detail with reference to Christian discourse on sin. The argument proceeds in three steps. Firstly, some background is offered on root cause analysis as a tool for social analysis. Secondly, the root causes of global environmental destruction are traced backwards to the role of worldviews ('modernity') and religious constructions of ultimate reality with reference to the critique against Christianity by Lynn White and others. Thirdly, this analysis is then related to the form of social diagnostics found in Christian discourse on sin. How is the underlying problem perceived? This question is addressed with reference to five classic notions of sin each with a modern correlate found in environmental discourse, namely moral shortcomings (prompting alleged needs for education, economic growth and development), pride (anthropocentrism), greed (consumerism), violence (domination in the name of differences of species), and the privation of the good (alienation from the earth). The last of these resonate well with traditional African notions of land. It also suggests the possibility of ultimate perspective on such root causes of environmental destruction within a Christian context, namely in terms of a broken relationship with the triune God.
\end{abstract}

Key Words: $\quad$ Africa; Environment; Hamartology; Penultimate; Root Cause Analysis; Sin; Ultimacy

\section{What are the Causes of Environmental Destruction in Africa?}

There is no need here to sketch the impact and scope of environmental destruction in Africa. Others may do so with much more expertise. One may merely list the obvious concerns, namely over the long-term impact of global climate change on food security, the impact also on food security of wide-ranging desertification and deforestation (resulting from the pressures posed by population growth, urban sprawl and commercial agriculture), the associated loss in biodiversity, the impact of mining together with oil and gas extraction on precious fresh water supplies, for example through acid mine drainage (e.g. in South Africa and Ghana), and the unhygienic living conditions of Africa's urban poor, partly as a result of waste dumping and inadequate waste management.

This article is based on a keynote paper presented at $6^{\text {th }}$ Conference of the African Association for the Study of Religions on "Religion, Ecology and the Environment in Africa and the African Diaspora", held in Cape Town, 30 July to 2 August 2014. 
Most of the problems experienced by Africa's urban poor on a daily basis (with the exception of unemployment which is related to environmental destruction only indirectly) are in fact environmental problems, even if not always recognised as such. The list includes diseases resulting directly from air and water pollution, inadequate housing in already contaminated areas of low economic value, ubiquitous problems around sanitation, the daily search for firewood, the emotional impact of living amidst filth and squalor and local political conflict over scarce resources (see already Lawson 1991).

These problems are of such a nature that the only appropriate response may be lament over so much destruction, so much beauty irrevocably lost. In this contribution I will adopt a different genre by investigating the root causes of such environmental destruction in Africa. The rationale for such an inquiry should be obvious. The question is this: If we are on the road towards self-destruction and know that all too well, why don't we just stop (see Rasmussen 2013:89 and the discussion below)? This suggests that the problem is not merely a scientific, political, economic or technological one. It is a moral problem and, given our collective inability to do what we know we need to do, indeed a spiritual problem.

It is not difficult to offer provisional answers to this question. Let me, by way of introduction, offer a few possibilities:

Most, I presume, would blame this directly upon Western imperialism and colonialism. Some may respond that such imperialism and colonialism is based on the scramble for Africa's natural resources and would argue that although colonialism is officially something of the past, such a confiscation of resources continues unabated, for example to satisfy the need for such resources in the vast Chinese economy. Others may point out that capitalism becomes manifested not only in the monopolisation of resources but also the exploitation of labour and the control of markets. Globalised neo-liberal capitalism has created stark economic inequalities also within Africa. This is the driver of rising social expectations amongst the emerging middle class, while Africa's poor have to fend for themselves from whatever resources might be available. Accordingly, the root causes of environmental destruction may be found in such economic inequalities albeit that the environmental impact of the lifestyles of the affluent and the poor is different in kind and severity (see Nürnberger 1999).

Yet others would agree but would want to add that the production of wealth takes place for the sake of consumption. This would suggest that social and indeed cultural factors also play a role. Accordingly, the deepest causes of environmental destruction are related to cultural expectations regarding people's standard of living, coupled with contested notions of what 'civilisation' entails. This may help to explain the motives behind colonialism but also to indicate that such drivers of ecological destruction are also found within the African context, in the appropriation of such standards of living amongst the emerging African elite and in the aspirations and upward social mobility of many others. The blame for ecological destruction would then be related to the internalisation of outside forces. The problem remains an imbalance of power; but such imbalances are found also within Africa, as indicated in the distinction between centre and periphery that has global, continental, national and local dimensions (see Nürnberger 1999). If so, Africans are indeed the victims of environmental injustices but cannot merely put the blame on outside forces beyond their control.

One may also argue that such shifting social expectations are fuelled by various mechanisms that are designed to promote such upward social mobility. These of course include aggressive marketing - for the sake of enhancing the market share of those who already 
dominate such markets - that leaves some despondent while stirring the imagination and desires of others. Moreover, one may point to the role of education (still largely based on notions of civilisation amongst the Western elite) and especially to the disastrous role of development. There can be little doubt that ecological destruction in Africa since the 1970s is deeply intertwined with the failure of development agendas - and more specifically with the associated international debt, internal corruption over the control of international loans and structural adjustment programmes imposed by the World Bank and the International Monetary Fund for the sake of 'development' in Africa (see e.g. Mugambi \& Vähäkangas 2001, also Moyo \& Ott 2002).

Two comments on this provisional analysis may suffice: Firstly, particular ideologies such as imperialism, colonialism, capitalism and cultural elitism typically inform economic practices that have a destructive environmental impact. The ideological roots of the underlying problem therefore have to be addressed. Secondly, the contestation over the roots of the problem is related to the extent to which external forces have become internalised. Should environmental destruction be blamed mainly on the West and now also the East, or are Africans deeply complicit in this regard? On a personal note I need to confess that these ideologies are indeed internalised and reinforced through the board games that my children like playing (preferably with me!), namely Risk (militarism), Settlers of Catan (imperialism), Monopoly (capitalism) and Scrabble (cultural elitism - which is far from innocent).

In the discussion below I will test and develop these provisional comments on the root causes of environmental destruction in Africa by following a series of further steps.

\section{Some Observations on Root Cause Analysis}

Drawing from various popular and readily available internet sources, one may say that root cause analysis is a method of problem solving that tries to identify and address the root causes of problems as opposed to simply addressing their symptoms. Root causes are distinguished from other causal factors (in a fault sequence) that also affect outcomes but are not the root cause. It may help to address such causal factors but this would not prevent the problem from recurring. Focusing on the root causes instead, may prevent problem recurrence. The root cause is often taken to be the main cause, but it is better to understand it as a cause lying beneath the surface (like the roots of a weed) that is not immediately obvious but is nevertheless the origin of the symptoms that are identified.

In its simplest form the method used in root cause analysis entails first the identification and accurate description of a problem that occurred, specifying its nature, magnitude and location on the basis of collected data. This is followed by the identification of a list of possible causal factors. These may include physical causes, human causes and organisational causes (a system or policy that people use in making decisions). The simplest way to identify such causal factors is to ask the question why something occurred and to repeat that several times in order to identify the root cause. It is said that five such steps would usually suffice. The trick is to ask appropriate questions. It is then necessary to establish a sequence of events to understand the relationships between such causal factors and the identified problem. On this basis one may identify, recommend and implement solutions. It is therefore best understood as a reactive method of identifying the causes of problems but may also be used on that basis as a pre-emptive method to predict and then avoid probable problems before they occur.

One interesting example relates to the Washington monument in Washington DC. It was 
discovered that the monument is eroding and that the rate of erosion is increasing. Why? Apparently, this was due to harsh chemicals used to clean the pigeon poop off the monument. Should other chemicals be used? This may be the solution but then the problem with the pigeon poop would not be addressed satisfactorily. Root cause analysis suggests the need to ask why the pigeons are there in the first place. It turns out that pigeons like spiders and that spiders were nesting on the monument. Why were the spiders there? Spiders like gnats and gnats were flocking to the monument in increasing numbers. Why? They are attracted by the lights that bathe the monument after dark. These lights were switched on the same time each day, not accounting for seasonal changes. So the solution was relatively easy, namely to address the root cause of the problem, by switching on the lights later and well after dusk according to the seasons. No lights means fewer gnats, fewer spiders, fewer pigeons, less pigeon poop, less need for harsh chemicals and less erosion.

This solution may seem obvious after the analysis but this is not immediately evident for the cleaners tasked to combat the problem of pigeon poop. It is only once all the factors are identified and when the cleaning staff is brought into contact with the person responsible for the automated lighting that a solution can be found. One may use this kind of analysis to investigate a range of recurring problems at home or at work - if the tearoom is in a mess, if pass rates for a particular module are low or if large numbers of students are registering late each year. In each case this may help to address the causes instead of the symptoms of a problem.

Apparently, root cause analysis was first introduced by NASA in the complex field of rocket design. It does make sense as a way of avoiding aircraft accidents from recurring. In the literature on root cause analysis the role of Japanese motor vehicle manufacturing companies is often mentioned. The so-called fish-bone diagram was developed in this context in order to map cause and effect with reference to the role of people, the environment, raw materials, processes and so forth. Root cause analysis is not a single, sharply defined methodology though. There are different tools, processes and philosophies for performing a root cause analysis in the fields of production, health care, safety and security, maintenance (systems failure), risk management and so forth. It is best understood as a tool for management practice and is less helpful in addressing complex social problems such as poverty, HIV/AIDS or violence against women. It is therefore not necessarily appropriate to use this form of analysis to address something as complex and systemic as the destruction of ecosystems in Africa, unless only localised problems such as oil spills are addressed. I will nevertheless use the terminology if not the necessarily the methods because identifying the root causes of something is indeed important for any form of social diagnostics.

\section{The Root Causes of Global Environmental Destruction}

There can be little doubt that humanity has had an adverse impact on the bio-physical environment already from the time that hunters and gatherers spread from Africa all over the globe (see Ponting 1991). However, such impact remained limited due to relatively low population figures, much lower levels of per capita consumption and technological sophistication. Wherever humans developed better tools, they used them for productive but also for destructive purposes. There is more or less consensus in the literature that current forms of environmental destruction follow from three revolutions that changed the shape of human societies, namely the expansion of human foragers after the 'cognitive revolution' from around $70000 \mathrm{BCE}$, leading to the extinction of numerous larger species in every 
geographical context including Australia, the Arctic, the Americas and various islands (see Harari 2014:3-83), ${ }^{2}$ the agricultural revolution since around $10000 \mathrm{BCE}$ (at first in Egypt and Mesopotamia) and the industrial revolution since 1750 (at first in England and Germany). We are in the midst of another, namely the information revolution (at first in Silicon Valley), but in each case the next revolution assumes previous achievements and exacerbates their environmental impact (see Rasmussen 1996:53-74). The information revolution may in future help us to cut down on the use of paper, but it is abundantly clear that even though agriculture, mining and industry form a much smaller section of the economy than in the past, the total bio-physical throughput of the global economy is still expanding (albeit not proportional to GDP growth).

Following the logic of root cause analysis one may say that if the industrial revolution is the root cause of current environmental destruction and if the benefits of the industrial revolution (arguably for at least half of the human population) are obvious in terms of health, food and standard of living, then there is no easy solution available. This is illustrated by the widely discussed formula $\mathrm{E}=\mathrm{P} \times \mathrm{A} \times \mathrm{T}$, i.e. environmental impact is a function of population, consumption (affluence) and technological sophistication. Since all three these factors have climbed exponentially, it is difficult to see where a solution may be found. Few economists would welcome a drastic decrease in the human population (what would that do to the economy!); even fewer would willingly lower their standard of living before retirement and more advanced technology would always be welcome.

But what are the causes of the industrial revolution? One may give many answers but a simple one would do, namely the widespread introduction of technology such as the steam engine that changed the means of production in industrialised economies decisively. The steam engine was indeed the prototype for all further technologies in industrialised societies and is still the underlying technology that provides the main source of energy for the global economy by burning fossil fuels. This is of course directly related to global climate change. If such technology is indeed the root cause of environmental destruction, the solution would lie in developing alternative technologies based on other sources of energy (the ' $T$ ' in the formula above). The challenge posed by climate change is to alter the energy base of the global economy by reducing its carbon footprint by at least $50 \%$ within the space of let us say 6 decades as from 1990 - of which the first 2 decades were the most important. One may add qualifications to this bottom line. Some would say that the problem can be alleviated through raising efficiency standards - which will certainly make a difference but would be cancelled out by soaring global demands for energy, especially in so-called developing economies (the Jevons paradox). Another qualification is based on the principle of a common but differentiated responsibility: Countries with high historic carbon emissions should reduce their carbon footprint by around $80 \%$ in order to allow industrialising economies some breathing space to make increasing use of fossil fuels before a transfer of technology can be achieved. This is certainly appropriate for the sake of justice but not if this diverts the attention away from the primary task of reducing $\mathrm{CO}_{2}$ levels in the earth's atmosphere. It would not help us as Africans much to demand our fair share of time and space on the upper-deck if the ship is the Titanic and if the catastrophe will hit us the hardest.

This suggests that the root of the problem is not technology as if technological innovation by itself can resolve environmental destruction in Africa. So we need to probe 
deeper by asking: What are the root causes of such technological innovation? Again there is a simple answer, namely the rise of modern science that stimulated a climate of invention. In very broad strokes the industrial revolution has to be understood against the background of the intellectual climate that emerged in Western Europe on the basis of the Renaissance (in Italy), the $16^{\text {th }}$ century Protestant reformations, the voyages of exploration and exploitation (spearheaded by Portugal and Spain), the emergence of mercantile systems based on that (through Dutch, French and British imperialism), drawing in resources from around the world and slave labour especially from Africa, the (German) Enlightenment that followed in the wake of the religious wars of the $16^{\text {th }}$ and $17^{\text {th }}$ centuries, the call for freedom, equality and brotherhood associated with the French revolution and the emergence of mercantile and later industrial capitalism with its forms of entrepreneurship and corporate management of risk.

Upon further reflection, this shift in intellectual and cultural climate may be captured in a single word, namely the rise of modernity. For many there is little doubt that (the worldview of) modernity is indeed the root cause of current environmental destruction. More specifically, this may be described as the logic of domination and control. This is especially evident from the split between subject and object associated with Descartes, widely regarded as the father of modernity. This stimulated empirical investigation (already the difference between Copernicus and Galileo) and the subsequent quest for knowledge, truth, certainty and control. Immanuel Kant represents the spirit of this age with his call to think for oneself, even if he already undermined this quest with his analysis of the limits of pure reason and practical reasoning. Feminist critics have suggested that the same underlying logic of domination is also evident in patriarchal relationships. The environmental crisis is the outcome of the extrapolation of this logic of domination and exploitation by seeing nature mainly in terms of natural resources (see e.g. Ruether 1992). As others have added, this is a logic of domination in the name of the differences of gender, race, culture, caste, class, sexual orientation, education, species and kind. If that is the case, what is required is the fostering of relationships based on mutual respect and reciprocity.

Some would argue that we are witnessing a transformation of the cultural and intellectual climate away from modernity towards postmodernity. This is certainly associated with less certainty, but others would counter that such thoughts can only be entertained by the leisured classes - whose lifestyles are inseparable from the systemic violence associated with late-modern, industrialised and now neo-liberal capitalism. Yet others therefore offer a critique of empire and engage in postcolonial discourse in order to address the underlying logic of domination. This is in my view indeed appropriate but only if it is recognised that such discourse is still determined by what is criticised (as the term post-colonial suggests) and not by articulating viable alternatives. If a different world is possible, one that has never existed before, as the Global Social Forum dreamed, how is this to be imagined?

Can one go deeper than modernity in analysing the root causes of global environmental destruction? One may raise the question why modernity emerged where it did and when it did. Why did modern science not emerge in Egypt or in China with its ancient civilisations - or in the cradle of humankind in Eastern or Southern Africa? This is of course a sensitive question given a sense of externalised superiority (white supremacy) and of internalised inferiority so readily associated with that. This is the question that Jared Diamond addresses in his book Guns, Germs and Steel (1998) - by pointing first of all to plant and animal species that were available to be domesticated in certain parts of the world and that facilitated the establishment of towns, kingdoms and civilisations. There is no need to explore the validity of his argument here. I do think it is necessary for us as Africans, if 
only for the sake of honesty, to address this kind of question given the way in which we have so willingly and readily adopted the technologies (guns, motor vehicles, television and cell phones) and some cultural patterns (notably soccer) emerging from the Western world.

There is one famous answer to this question, namely that the deepest roots of global environmental destruction are related to the emergence of Judaism, Christianity and Islam. This is the thesis posed by the American historian Lynn White in his article entitled "The historical roots of our ecological crisis" first published already in 1967. He argues that Abrahamic religion is deeply anthropocentric and that Christianity, in particular, bears a "huge burden of guilt" for such destruction. The details of his argument on the distinction between Creator and creature, on the subsequent disenchantment of nature, the exegesis of Gen 1:28 and the notion of stewardship need not be explored here. Four brief comments would suffice:

Firstly, Christianity is widely interpreted as having provided religious legitimation for the upward mobility of the nations of Europe and later North America. There can alas be little doubt that this is what still attracts many in Africa and Asia to Christianity. When confronted with the technological power and relative wealth of Europe, people may well assume that Christianity is the inner secret of such progress. Secondly, the argument of White and others has nevertheless been highly contested on historical grounds despite the obvious role that Islam and then Christianity played in the emergence of modern science. Thirdly, there can be little doubt that Christianity does share a "huge burden of guilt". This is already illustrated by the correlation between countries with high historic carbon emissions and countries where Christianity was well-established at the time of the industrial revolution. If Christians did not cause the problem they at least tacitly legitimised such cultural patterns or failed to unmask the underlying tendencies. The complicity is also suggested by the alignment between neo-liberal capitalism and rightwing evangelicalism - which is, from the perspective of religious studies, undoubtedly the dominant form of religion/ideology currently operative in the world. Fourthly, given such guilt, apologetic approaches to defend Judaism, Christianity and Islam against such accusations are inappropriate. What is needed is a radical ecological transformation of each religious tradition, albeit that this has to take place in each case on their own terms (see Nash 1996, Conradie 2013, Conradie, Tsalampouni \& Werner 2016).

Has this exercise in root cause analysis enabled us to identify the very roots of the environmental crisis as being deeply religious? My sense is that this is what numerous African authors are indeed suggesting. They intuitively or explicitly sense the impact of the worldview of modernity, recognise the differences if compared with the assumptions embedded in an African worldview and seek to retrieve indigenous ecological wisdom from traditional African culture and religion on that basis. The underlying problem may still be located in different areas but these tend to be related: a recognition of the impact of visible but also invisible (spiritual) (life) forces (including the role of ancestors), the need for a cosmic balances of forces, an appreciation for a sense of enchantment, of the sacred and the sublime, a sense of circular or narrative instead of linear time, the need to identify and exorcise demonic forces (typically undermining social stability from the outside) and an almost overwhelming plea for social harmony based on notions of relatedness. In South Africa this is expressed by the term ubuntu that includes at least three connotations, namely that one's identity is partially constituted by the (radical) other, a sense of inclusive community and fellowship (that stretches beyond friends and insiders) and the need for hospitality toward those who need help, including strangers. Each of these connotations may be extended towards a community of life that is embedded and sustained in healthy ecosystems. 
Given the military, political and economic conflicts that rage in so many regions throughout the African continent, such pleas may easily be dismissed as romanticised. What would it help to long back for a bygone era? A sense of the sacred has seldom in history been sufficient to resist the abuse of new technologies. What about the real advances in terms of food and health care introduced to Africa on the basis of the industrial revolution? One may also wonder whether traditional communities in Africa were all that harmonious, given the role of patriarchy and the treatment of people with sexual orientations that deviated from the established norms. Either way, the forces that undermine such a sense of community are clearly stronger than those that replenish them (see Rasmussen 1993). Even if the root causes of environmental destruction can be identified on this basis as being deeply religious, it is by no means clear that this also suggests an avenue to find lasting solutions. Either way, I suggest that the substantive contribution that scholars in the fields of religion and theology can make to address environmental issues lies in probing this issue.

\section{Sin and Social Diagnostics}

One may take the exercise in root cause analysis one step further. If the roots of the problem are indeed religious so that it is impossible to address the problem without tapping into religious symbols, archetypes, myths and rituals, it may also help to investigate how the underlying problem is analysed in particular religious traditions. A warning has to be heeded though: If religion is part of the problem, then its diagnosis of what is wrong with the world may well be misleading, if not illusory. However, it may also help to remind others that the underlying problem should not be pathologised as if the problem (and therefore the solution) is merely medical or psychological. Here the term diagnosis may well be misleading.

In the discussion below I will draw mainly on the Christian and more particularly the reformed tradition within which I find myself. I trust that this will serve as an invitation to others to offer a similar analysis of diagnostic tools from within their own traditions. I will suggest that this diagnosis is indeed ambiguous but that it may still provide some vocabulary for the common purpose? of assessing what has gone wrong.

Christians would tend to capture the root causes of environmental destruction in one very brief word, namely sin. Given widespread cultural resistance against language about sin and guilt it may be futile to introduce such concepts. Moreover, the danger is that a preconceived diagnosis is presented even before the patient is examined. The remedy would therefore be dangerous and may well be tantamount to a form of witchcraft. Instead, I suggest that the Christian vocabulary of sin may be likened to terminology available to a doctor to describe a diagnosis based on knowledge accumulated from other medical case studies. This implies that the hard work of socio-economic diagnostics cannot be avoided or circumvented through religious short-cuts. The category of sin therefore cannot be introduced prematurely. It may be the last word on where the underlying problem may be found, not the first word. Or perhaps, as reflected in the title of this contribution, it may be an appropriate penultimate word. If God may be regarded as the ultimate "mystery of the world" (Jüngel 1983) and if God-talk is practised in an arcane and doxological way to express a last word beyond which all other words dry up, then the category of sin may function in a similar way as a penultimate assessment, following in-depth diagnosis, of the nature of the predicament, the malaise of society, the deepest roots of environmental destruction. 
Christian reflection on sin has been plagued with numerous impenetrable questions throughout the centuries. Where does sin come from? From the temptation of evil (symbolised by Eve and the 'apple')? But where does evil come from? From the devil? But then where does the devil come from? From God? Why is there suffering and injustices in God's supposedly good creation? Is sin indeed inescapable (i.e. 'original') so that I was born (in 1962) within structures of violence that were not my own doing but within which I am necessarily complicit? How serious is sin? Are we totally depraved as some of Calvin's followers would have it? Or is there also something good in every human being and indeed every creature - as the humanist and liberal followers of Pelagius still maintain? Is the function of religion then one of moral encouragement? If so, do we need to save ourselves from evil by mustering the available forces of goodness with a bit of divine grace? Do we have to "save the planet" ourselves from anthropogenic climate change? Another question: How does one recognise sin in the first place - if it tends to hide itself through deception and illusion? Is Barth correct that sin is only fully recognised when we are shamed by the forgiveness of sin, when we have already grasped the solution?

The crucial question is on the very nature of sin. The best scholars have always come to the same conclusion, namely that sin cannot be defined since that would imply that it can be identified, contained and be overcome. Instead, one may say that sin is like a hydra, a monster that appears in new forms every time its head is severed from its body (see Migliore 2004:153). The strategy employed in medieval times to warn against at least seven deadly sins - usually wrath, avarice, sloth, pride, lust, envy and gluttony - may therefore be quite appropriate (see Peters 1994).

This conclusion has not impeded theologians from trying to capture some of the characteristic features of sin. In this contribution I will explore five such classic approaches and will show how these have been employed in Christian ecotheology and in a secular context to identify the root causes of environmental destruction. It is in my view remarkable how fruitful the traditional Christian vocabulary has proved to be on the nature of $\sin$ (for a survey of the literature see Cloete 2013). Sin is at once manifested in a lack of education and development (sloth), anthropocentrism (pride), consumerism (greed), domination in the name of difference (violence) and human alienation from the rest of nature (the privation of the good). In conclusion I will show how this may be relevant within the African context.

\section{Sin as moral shortcomings (backwardness)}

One of the classic descriptions of sin in the biblical roots of Christianity is that of harmartia (see 1 Cor. 6:18), derived from the Greek verb hamartano, indicating an arrow falling short of its target (see Hall 1993:221). This notion of sin may be understood in terms of a sense of holiness. Anything less than full devotion to the Holy One would lead to exclusion. It is therefore not merely a matter of shortcomings that can be graded so that anything less than let us say $50 \%$ would be regarded as a moral failure. Alternatively, this may be understood in terms of covenant obligations. Falling short of what the covenant stipulates would lead to exclusion from the divine blessings that the covenant secured. This notion of sin as shortcomings invites further reflection on specific acts of wrongdoing - including murder, rape and theft, but also adultery, defamation, regulations around not keeping the Sabbath and a whole long list of vices. In a secularised context this may be reduced and trivialised to smoking and drinking on which 'sin tax' has to be paid.

One may argue that this diagnosis of the human condition in terms of moral 
shortcomings has become extremely influential in modern industrialised societies. In a secularised form this yields a notion of a society where people are graded according to their moral standing. This may be understood in terms of personal virtues and vices. In the context of industrialised capitalism, however, such virtues are understood in terms of creativity, entrepreneurship, diligence, punctuality, efficiency and so forth. The vices then include laziness, stupidity, inefficiency, backwardness and barbarism. In short, sin is easily understood here in terms of the deadly sin of sloth. It does not refer to what one has done but what one has failed to do or left undone.

If $\sin$ is understood in such terms, it is easy to see how 'salvation' may then be interpreted in terms of development, progress, economic growth, industrialisation, civilisation and (for many) simply Westernisation. The means through which this has to be achieved is through education and training. This assumes that our main problem is ignorance, so that acquiring appropriate knowledge will make the difference between making it in life or not. This assumption is apparently widely endorsed in the South African context - leading to equally widespread concerns over the quality of education. However, at least in moral terms, it is a liberal fallacy to assume that knowledge of the good is sufficient for the realisation of the good. To know that I need to love my neighbour as myself will not necessarily lead me to act accordingly. Likewise, knowledge of how the HI virus is transmitted will not by itself lead to appropriate sexual behaviour.

This diagnosis of the underlying problem and the prescribed remedy has prompted vehement responses in the context of ecotheology also and especially from within the African context. The assumption is that salvation for all Africans is to be achieved through higher economic growth so that everyone will receive (or simply take!) a larger slice of the proverbial cake. As John F. Kennedy famously stated, a rising tide should lift all boats (for a critique see Rieger 2009). However, insofar as such economic growth assumes a more intensive use of resources and a higher biophysical throughput, it must be said that infinite economic growth is not possible on a finite planet. A rising tide in one half of the world implies a subsiding tide in another part of the world. Moreover, given the control of markets by powerful companies in a supposedly liberalised economy, the increased production of wealth does not necessarily lead to economic equality. There may have been some trickle-down effect but the trickle-up effect is even more evident. This applies globally but also within the African continent and within particular national economies. For those who fall behind the targets for economic growth the remedy that is prescribed to 'catch up' (and is accepted by many) is development. As noted above such a notion of development has had disastrous economic and ecological consequences in Africa in recent decades. The problem for ordinary people is that there is only one thing that is worse than development is that is falling so far behind that one is rendered unemployable in a servicebased economy. There is only one thing that is worse than having a loan from the World Bank (with all the strings attached) and that is not having such a loan.

\section{Sin as pride (anthropocentrism)}

In the biblical roots of the Christian tradition sin is often described in terms of hubris, arrogance or pride. This is readily associated with sin as rebellion against God, unbelief or idolatry. Accordingly, sin is not just a form of arrogance but a way of putting one's trust in things that are ultimately not trustworthy. This notion of sin has remained influential throughout the ages, albeit that it is undermined by the modern and also postmodern emphasis on the need for self-respect, self-affirmation, self-confidence, self-realisation and 
indeed on 'loving oneself'. It is not difficult to see how this is related to the heretical turn to the subject prompted by Descartes' cogito ergo sum and Kant's cry on behalf of the Enlightenment: "Dare to think for yourself!" However, this may also help us to see how the emphasis on the self is dialectically related to the denigration of oneself - which prompts the very need for self-affirmation.

In secular reflection on the root causes of environmental destruction (but echoed in many contributions to ecotheology) this notion of $\sin$ is re-described as anthropocentrism. This is the assumption that non-human nature has only instrumental value for us as humans and not also intrinsic value. If so, one would need to conclude that the whole history of the universe is there only for our sake. This is cosmologically naïve, highly arrogant and downright silly. Nevertheless, such anthropocentrism is difficult to avoid. For one, we seem to need a way of distinguishing between household pets and household pests. We need some justification to slaughter chickens for food but not children. Most standard ethical theories are based on such a form of anthropocentrism (see Desjardin 2012). Even where the intrinsic value of non-human animals is affirmed, an equal intrinsic value is seldom acknowledged so that such value has to be graded, typically using norms that remain deeply anthropocentric. Others have argued that it is impossible for humans to perceive nature in any other way than as human beings so that some form of anthropocentrism seems inevitable. In response, a distinction may be suggested between what is anthropogenic and what is anthropocentric. We may be the only measurers of things (although that is debatable too) but this does not imply that we are the measure by which everything else has to be judged (see Rolston 1988:32).

Amongst the many examples of such a notion of sin, one may mention Sallie McFague's view that sin is "the refusal to accept our place" (1993:112). This is born from a new appreciation for the situatedness of human beings within the larger earth community, for the need for a sense of place (McFague 1993:100-103). The question is no longer how the relationship between human beings and nature is to be understood because we form part of nature. McFague offers the following three reasons for a theological retrieval of space and place: a) Space is a levelling, democratic notion which places us on a par with all other life forms. b) Space highlights the relationship between ecological and justice issues, for example wherever conflict over arable land emerges. c) An emphasis on space helps us to realise that the earth is our home, that we belong here, and that this is not only our space but also our place.

On this basis McFague (1993:34) comments on the malaise of the human condition: "We have lost the sense of belonging in our world and to the God who creates, nurtures, and redeems this world and all its creatures, and we have lost the sense that we are part of a living, changing, dynamic cosmos that has its being in and through God." Accordingly, sin may be understood as the refusal to accept our place, to know and to accept our limitations. My sense is that such a notion of sin is attractive for many in Africa who see the roots of environmental destruction mainly in terms of Western arrogance in refusing to accept their place by invading the places of others. Traditionalists would warn against the temptation to internalise this sense of superiority either through an inferiority complex or by imitating Western (American) culture.

\section{Sin as greed (consumerism)}

In the biblical roots of the Christian tradition sin is also described in terms of greed or avarice. This is readily associated with sin as selfishness, jealousy and egocentrism. It is 
exemplified by sexual lust, hoarding riches, over-indulging in food and a lack of temperance. This notion of sin, too, has remained influential throughout the ages. It is obviously a driving force behind the accumulation of capital and expressed in vices such as hedonism, consumerism and so forth. In contemporary culture advertisements often offer a justification for lust, desire, greed and hoarding (in the name of ensuring a viable retirement package). The verdict of Alberto Múnera (2000:68) on globalised capitalism may suffice here: "It is the rule of the greedy, for the greedy, and by the greedy."

In contemporary reflection on the root causes of environmental destruction this notion of $\sin$ is re-described as consumerism. Consumption is of course a necessary human activity. People have the need to consume resources in order to survive. The poorest sections of the world's human population need to consume more resources if they are to lead dignified lives. The meaning of the term 'consumption' is slippery since it is not immediately evident what is being consumed. Strictly speaking, since neither matter nor energy can be created or destroyed, no product can be literally consumed - production and consumption are really nothing more than a rearrangement of matter but then in such a way that something that is consumed is no longer available for others. Some would say that what is consumed is the value added to nature, but that would underestimate the preexisting value of the building blocks (e.g. coal) to which value is added through economic production (e.g. of electricity) and which are indeed receptive to such value being added. Following economist Herman Daly and many others, it may therefore be more appropriate to describe consumption in terms of throughput: "the flow beginning with raw material inputs, followed by their conversion into commodities, and finally into waste outputs" (see Crocker \& Linden 1998:7). Others would argue that what is being consumed is meaning. Consumers purchase products because of the cultural connotations (or branding) attached to such products. Such connotations are highlighted through packaging and exploited by the advertising industry. On the basis of such connotations an act of consumption may also become a vehicle for communicating with other consumers. Consumer items thus function as symbols through which consumers interact with others, for example, in conveying social status.

If consumption is necessary, a critique of consumerism therefore has to focus on the need for moderation. Too little consumption leads to starvation and too much consumption to constipation. The question, as posed by Alan Durning (1992) in his often quoted work with the same title, is therefore "How much is enough?" The term 'consumerism' refers to a cultural orientation that is quite evident amongst but not restricted to the consumer class. It has spread rapidly from the consumer class in North America, to Europe, the Far East and is now a dominant cultural force in almost every single country. The lifestyles of the consumer class, together with the power of the media and a bombardment of advertisements, have ensured that consumerism now describes the hopes and aspirations of the poor and the lower-middle class almost everywhere in the world.

In a survey of Christian literature on consumerism I identified the following six points of entry for a critique of consumerism (Conradie 2009):

- An ecological critique: The consumer society is not sustainable;

- An economic critique: Consumerism exacerbates economic injustices;

- A social and psychological critique: The affluent have become the victims of their own desires;

- A virtue ethics critique: Consumerism undermines virtue and breeds vices; 
- A hermeneutical critique: The consumer society encourages commercialised cultural and religious practices; and

- A theological critique: Consumerism amounts to idolatry.

For my purposes here it may help to comment on the fourth of these critiques, namely on consumerist vices such as envy, haughtiness, wastefulness and especially greed. Greed is the rapacious craving for more goods or wealth than one needs or deserves (Kavanaugh 2006:12). It enslaves people and destroys community and is therefore rightly regarded as one of the mortal sins. Greed is based on delusion: the delusion that happiness is to be found through either accumulation or consumption. Three manifestations of greed may be identified: the excessive desire for acquiring possessions, the desire for hoarding money and the closely related vice of covetousness which includes the desire for the possessions of others. This critique of consumerism thus focuses on the apparent insatiability of consumers. As Richard Foster (1978:71) notes, the lust for affluence in contemporary society has become psychotic: "It is psychotic because it has completely lost touch with reality. We crave things we neither need nor enjoy. We buy things we do not want to impress people we do not like... Covetousness we call ambition. Hoarding we call prudence. Greed we call industry." Such a critique of the vices embedded in the consumer society is perhaps the dominant point of entry for a critique of consumerism in Christian discourse. As Steven Bouma-Prediger (2001:167) observes, Christians can scarcely condone such materialism and consumerism: "Given the God we serve, can we justify a way of life predicated on the inordinate desire for that which moth and rust consume?"

Tragically, the whole 'global village' has come under the spell of the 'American dream' of the pursuit of happiness here and now. The American way of life is exported almost everywhere. Consumerism has become the dominant cultural trend in the whole world, certainly also in Africa. And, as Richard Foster once commented about money: "Those who have it the least, love it the most." The hope and yearning of the world's poor is to achieve an equally affluent standard of living. The hope of the poor is typically based on what money can buy too. They dream of instant prosperity. Kenyan theologian Mary Getui (1999:65) comments: "In Africa today, while some employ fair and just ways in acquiring material possessions, there are others whose strategies and methods are to their own detriment and that of the whole society. It is a mad rush in a bid to acquire as much as possible - houses, land, cars and any other material possessions - within the shortest possible time."

\section{Sin as power/domination}

In the biblical roots of the Christian tradition sin is also described in terms of domination, violence and oppression. This is readily associated with rape, murder, slavery and various forms of verbal aggression. Although one may focus on individual acts of violence, it is necessary to understand sin here not only as an act incurring guilt but also as a power that becomes embedded in the structures of society. It is a power within which both victims and perpetrators become trapped and into which children are born and raised. In contemporary terms this is best understood as structural violence, a sociological concept derived from the peace research of Johann Galtung. Structural violence refers to the physical, psychological and spiritual harm that some experience as a result of an unequal distribution of power but also to the complicity and acquiescence of those who benefit from that (Moe-Lobeda 2013:72). The prime examples of such structural violence include the ideologies of racism, classism and sexism but it also becomes evident in economic inequalities, the build-up of 
weapons and anthropogenic climate change. Structural violence typically leads to a spiral of violence that includes revolutionary violence and repressive violence, typically endorsed by the ideology of state security. Apartheid in the 1980s offers an obvious example.

Amongst the many examples of this notion of sin one may draw on Larry Rasmussen's recent book Earth Honoring Faith (2013). He offers an excellent diagnosis of the problem underlying ecological destruction. He acknowledges that language about original sin obscures more than what it reveals, but there can be no doubt about the persistence of what Rasmussen (2013:100) calls 'pervasive perversity'. Following observations from Daniel Quinn's text Ishmael Rasmussen (2013:89) raises the question of why we don't just stop when we know that we are destroying the world around us. Why do the injuries of nature delight us? He considers various answers: a lack of compassion, a reductionist utilitarian logic, a managerial anthropocentrism, ignorance of the consequences, human arrogance as a self-segregated species, turned in upon itself (cor curvatum in se), setting itself apart from the community of life, the abuse of power and privilege together with the inequalities and injustices that flow from power imbalances as a result of greed (the will to power), and pervasive ideologies.

Rasmussen then offers a constructive contribution on the basis of a rereading of the ethic of masters and slaves. He describes the Earth/human relationship as one of subjectover-object and mind-over-nature that yields a "paradigm of domination that renders nature essentially a slave to humanity, its steward and master" (2013:100). He criticises a stewardship ethic on this basis, reminding us that white Christian slave-owners considered themselves to the good stewards of slaves. The rest of nature has become enslaved to serve human purposes. Rasmussen adds: "Slaves are certainly not dispensable. But they are replaceable; one can substitute for another. This is the master/slave ethic in pure form" (2013:100). He adds that it is unnerving to realise how 'natural' this relationship has remained for self-appointed stewards of nature given how stewardship mimics the relationship between master and slave even though slavery is no longer permitted.

Rasmussen is very much aware of how such a master/slave dialectic becomes embedded in the structures of society. He labels this 'structural sin'. He observes that the prophetic imagination has a keen sensitivity for institutionalised practices, the habits by which we live. He says: "The practices of systems and structures are the true judges of how we're doing. Ideological claims, creeds, beliefs, rituals, and the noise of solemn assemblies pale alongside routine practice as the measure of our lives" (2013:306). He adds provocatively: "Tell us your income and your zip code and we will tell you how you live and the world it creates. We'll describe your education, diet, energy use and transportation. We'll describe the housing you have, the company you keep, the way you spend your leisure time, and how you treat your neighbours and the world" (2013:306). This, he also observes, applies irrespective of religious persuasions. Such structures of domination call for prophetic critique - and leads Rasmussen to a discussion of Dietrich Bonhoeffer, Martin Luther King Jr. and Mohandas Ghandi.

\section{Sin as privation of the good}

In Christian reflection on the nature of sin the same conclusion is reached again and again, namely that sin cannot be defined. If it could be captured in a single formula it might have been possible to isolate and remove the problem. Instead, sin is seen as elusive and hideous, re-emerging in new forms. The best theologians, mainly following Augustine, have con- 
cluded on this basis that sin is not so much some or other thing; it is the negation of something, the privation of the good, the distortion of relationships. Accordingly sin cannot be identified with any particular individual or collective deed, word, attitude or predisposition. It is not so much something that one does, but describes a situation in which one finds oneself, an embeddedness from which one cannot escape, within which one is a victim but is also complicit to - albeit not equally so.

If $\sin$ is understood in relational terms as a broken relationship it has no ontological status. In a way, it does not even exist, at least not on its own. Accordingly, salvation does not add anything new to the world either. Instead, the salvation brought by the Christian gospel may be understood as a form of pruning (or surgery) where the invasive parasites that hinder growth are removed (and turned into compost) so that the indigenous plant (which is God's creature) can flourish freely, unencumbered by the destructive impact of $\sin$.

In ecological terms, this notion of sin is widely adopted and adapted to describe a sense of alienation. Such alienation may be understood in Marxian terms as alienation from the means of production and from the products of one's own labour, leading to alienation between management and workers. The classic critiques of alienation by Hegel, Marx, Toennies and the Frankfurt School may obviously be retrieved in this regard. In legal terms, alienation implies the disposal of property, whether fairly or unjustly. Likewise, in indigenous African terms it may be described as alienation from ancestral land. In religious terms, this is best understood as alienation from the earth itself following the conviction that the earth is not our home; that our true home and final destination is with God, in heaven, wherever that may be deemed to be located.

According to this diagnosis, people in industrialised societies have become alienated from the material dimensions of creation, including their own bodily existence. This form of alienation may indeed be viewed as the inner aspect of the external alienation evident in the late-modern industrial society. We have indeed for too long thought of ourselves as somehow separate from nature. This has led to alienation between human beings and nature. Larry Rasmussen (1996:75-89) refers to the 'apartheid habit' of distinguishing between humanity and non-human nature, leaving the impression that we are an ecologically segregated species, that we are somehow separate, hence 'apart' from the ecosystems in which we live. Rasmussen adds that the same 'apartheid habit' is also manifested in the 'great divorce' of nature from (human) history. Human beings and the history of humanity should be regarded as a mere episode in the larger history of the cosmos itself and of life in (not on) this planet.

A similar assessment of the alienation of human beings from nature is evident in the striking metaphor of 'autism' which Thomas Berry (1988:215) uses:

In relation to the earth, we have been autistic for centuries. Only now have we begun to listen with some attention and with a willingness to respond to the earth's demands that we cease our industrial assault, that we abandon our inner rage against the conditions of our earthly existence, that we renew our human participation in the grand liturgy of the universe.

Sallie McFague (1993:34) comes to the same conclusion: 
We have lost the sense of belonging in our world and to the God who creates, nurtures, and redeems this world and all its creatures, and we have lost the sense that we are part of a living, changing, dynamic cosmos that has its being in and through God.

Christianity, in particular, has been guilty of instigating, reinforcing and legitimising this alienation of human beings from the rest of the earth community. Christianity has all too often been preoccupied with an otherworldliness which did not encourage a sense of belonging here on earth. Instead, it fostered a 'sojourner sensibility' (McFague 1993:102). As I have argued elsewhere, this otherworldliness, this alienation from the rest of the earth community, is manifested especially in the following themes: 1) a theological emphasis on the absolute transcendence of God, 2) an anthropological emphasis on humans as sojourners here on earth, 3) a soteriology which focuses on human salvation from the earth instead of the salvation of the whole earth and 4) an escapist eschatological fascination with a heavenly hereafter where disembodied souls will live in the presence of God (see Conradie 2013).

In response, there is a whole chorus of voices affirming that we are "at home on earth" and indeed at home in the universe. In a wide variety of ecological theologies especially but not only within the African context there is an almost overwhelming emphasis on interrelatedness, on connectedness, on wholeness, on a sense of community, on intimacy instead of alienation. To mention one example amongst many others (see e.g. Asante 1985, Setiloane 1995), Harvey Sindima (1989:537) speaks of the bondedness, sacredness and fecundity of the "community of life":

The African idea of community refers to bondedness; the act of sharing and living in the one common symbol - life - which enables people to live in communion and communication with each other and nature. Living in communication allows stories or life experiences of others to become one's own.

Such an African notion of wholeness may easily become romanticised; it may well be an idealised vision for the future, retrojected into the distant past. It certainly also serves a prophetic critique of structures of domination in the neo-colonial present, a reminder that we are in fact not at home on our own ancestral land, at least not yet. Indeed, if the earth is our only house, it not our home yet. Our counter-intuitive sense of belonging is not an empirical description of the present dispensation but a function of an eschatological longing (see Conradie 2005). This is the kind of realism that Christian discourse on sin would tend to elicit.

\section{Conclusion}

I need to add a reminder that these remain penultimate perspectives on the root causes of environmental destruction globally and in Africa. Such penultimate perspectives are important because they open up possibilities for conversation between different religious traditions and with other spheres of society as to what has gone wrong. Given the widespread cultural resistance against the notion of sin, it may be helpful to allow for the full spectrum of secularised synonyms. As I suggested, such terminology remains contested but at least this allows for conversation towards a common diagnosis of what is by definition a common problem.

This is clearly also important in the African context given the contestation regarding where the real problem lies. Does it lie with population growth, with levels of consumption (affluence and consumerism) or with the impact of industrial technologies (or the lack of 
technological transfer)? Does it lie with development or the lack of development? Do the root causes of environmental destruction in Africa lie outside the continent, or do we have to accept that the same underlying problem is also found on the inside? My task cannot be to resolve such questions but to help elicit in-depth discussion in this regard. The role of religion cannot be restricted to provide motivational impetus to earthkeeping engagements but also includes an in-depth diagnosis of the underlying problem.

If these are penultimate perspectives, there is also a need to allow for the social construction of ultimate reality. What is of ultimate concern will necessarily offer an even wider interpretative framework within which penultimate concerns are placed in the perspective of what supposedly transcends reality as such. Here there may be less room to find consensus. No religious tradition that I know of is entirely satisfied with being classified as one religion alongside others precisely because each deals with what is nothing less than ultimate.

It is not possible to speak on behalf of any wider of narrower tradition, but I would suggest that ecumenical Christianity would do best to see sin not as something that we do (wrongdoing) but as a situation in which we find ourselves from which we cannot escape and within which none of us can claim innocence - although there is certainly a need to speak of the "proportionality of guilt" (see Conradie 2013:47-53). Indeed, sin is not something (that we do) but the privation of the good, best understood as a broken relationship. For Christians that means a broken relationship with the triune God. The doxological language of the Trinitarian confession is the very last word on the mystery of history (see Conradie 2015:25-174), albeit that it is best practiced in an arcane form and then as a word beyond which further words dry up, which is surpassed only by music and then by an encompassing silence. The Trinitarian confession is not a way of resolving that mystery but of naming, of whispering that mystery. If so, sin-talk is best understood as a redescription of what is ultimately wrong with the world.

\section{BIBLIOGRAPHY}

Asante, Emanuel 1985. Ecology: Untapped Resource of Pan-Vitalism in Africa. AFER:

African Ecclesial Review 27:289-293.

Berry, Thomas 1988. The Dream of the Earth. San Francisco: Sierra Club Books.

Bouma-Prediger, Steven 2001. For the Beauty of the Earth. Grand Rapids:

Baker Academic.

Cloete, Newton M 2014. Hamartology and Ecology: A Critical Assessment of Dietrich

Bonhoeffer's View on the Nature of Sin. MTh mini-thesis. University of the

Western Cape.

Conradie, Ernst M 2005. An Ecological Christian Anthropology: At Home on Earth?

Aldershot: Ashgate.

Conradie, Ernst M 2005. Towards an Ecological Reformulation of the Christian Doctrine of Sin. Journal of Theology for Southern Africa 122:4-22.

Conradie, Ernst M 2009. Christianity and a Critique of Consumerism: A Survey of Six

Points of Entry. Wellington: Bible Media.

Conradie, Ernst M 2013. Contemporary Challenges to Christian Ecotheology:

Some Reflections on the State of the Debate after Five Decades. 
Journal of Theology for Southern Africa 147:106-123.

Conradie, Ernst M 2015. The Earth in God's Economy. Berlin: LIT Verlag.

Conradie, Ernst M (ed.) 2013. Reconciliation as a Guiding Vision for South Africa? Stellenbosch: SUN Press.

Conradie, Ernst M, Tsalampouni, Ekaterini \& Werner, Dietrich (eds.) 2016. "Manifesto on an ecological reformation of all Christian traditions: The Volos Call”. In Werner, Dietrich \& Jeglitzka, Elisabeth (eds.), Climate Justice and Food Security:

Theological Education and Christian Leadership Development, 99-108. Geneva: Globethics.net.

Crocker, DA \& Linden, T (eds.) 1998. Ethics of Consumption: The Good Life, Justice and Global Stewardship. Lanham: Rowman \& Littlefield.

Desjardins, Joseph R 2012. Environmental Ethics: An Introduction to Environmental Philosophy (fifth edition). Toronto et al.: Thompson Wadsworth.

Diamond, Jared 1998. Guns, Germs and Steel: A Short History of Everybody for the Last 13,000 Years. London: Vintage.

Durning, Alan 1992. How Much is Enough? The Consumer Society and the Future of the Earth. New York: WW Norton.

Foster, Richard 1978. Celebration of Discipline. London: Hodder \& Stoughton.

Getui, Mary N 1999. Material Things in Contemporary African Society. In: Mugambi, JNK \& Nasimiy-Wasike, A (eds.): Moral and Ethical Issues in African Christianity: A Challenge for African Christians. Nairobi: Acton.

Hall, Douglas John 1993. Professing the Faith. Minneapolis: Fortress Press.

Harari, Yuval Noah 2014. Sapiens: A Brief History of Humankind. London: Vintage Books. Jüngel, Eberhard 1983. God as the Mystery of the World. Grand Rapids: Eerdmans.

Kavanaugh, John 2006. Following Christ in a Consumer Society: The Spirituality of Cultural Resistance. Maryknoll: Orbis Books.

Lawson, L 1991. The Ghetto and the Greenbelt. In: Cock, J \& Koch, E (eds.) 1991. Going Green. People, Politics and the Environment in South Africa, 46-63. Cape Town: Oxford University Press.

McFague, Sallie 1993. The Body of God: An Ecological Theology. London: SCM Press. Migliore, Daniel L 2004. Faith Seeking Understanding: An Introduction to Christian Theology. Grand Rapids: Eerdmans.

Moe-Lobeda, Cynthia D 2013. Resisting Structural Evil: Love as Ecological-economic Vocation. Minneapolis: Fortress Press.

Moyo, Fulata and Ott, Martin (eds.) 2002. Christianity and the Environment. Kachere Test No. 13. Blantyre: Christian Literature Association in Malawi

Mugambi, Jesse N. \& Vähäkangas, Mika (eds.) 2001. Christian Theology and Environmental Responsibility. Nairobi: Acton.

Múnera, Alberto 2000. New Theology on Population, Ecology and Overconsumption from the Catholic Perspective. In: Coward, H \& Maguire, DC (eds.): Visions of a New Earth: Religious Perspectives on Population, Consumption and Ecology, 65-78. New York: State University of New York Press.

Nash, James A 1996. "Towards the Ecological Reformation of Christianity", Interpretation, Vol. 50, 1:5-15. 
http://scriptura.journals.ac.za

Penultimate Perspectives on the Root Causes of Environmental Destruction in Africa

Nürnberger, Klaus 1999. Prosperity, Poverty \& Pollution: Managing the Approaching Crisis. Pietermaritzburg: Cluster Publications.

Peters, Ted F 1994. Sin: Radical Evil in Soul and Society. Grand Rapids: WB Eerdmans.

Ponting, Clive 1991. A Green History of the World: The Environment and the Collapse of Great Civilizations. New York: Penguin.

Rasmussen, Larry L 1993. Moral Fragments and Moral Community. Philadelphia: Fortress Press.

Rasmussen, Larry L 1996. Earth Community, Earth Ethics. Maryknoll: Orbis Books.

Rasmussen, Larry L 2013. Earth Honouring Faith: Religious Ethics in a New Key. Oxford: Oxford University Press.

Rieger, Jorg 2009. No Rising Tide: Theology, Economics and the Future. Minneapolis: Fortress Press.

Rolston, Holmes 1988. Environmental Ethics: Duties to and Values in the Natural World. Philadelphia: Temple University Press.

Ruether, Rosemary Radford 1992. Gaia \& God: An Ecofeminist Theology of Earth Healing. Harper \& Collins Publishers.

Setiloane, Gabriel 1995. Towards a Biocentric Theology and Ethic - via Africa. Journal of Black Theology 9:1, 52-66.

Sindima, Harvey 1989. Community of Life. Ecumenical Review 41, 4:537-551.

White, Lynn 1967. The Historical Roots of our Ecological Crisis. Science 155:1203-1207. 